\title{
Kernos
}

Revue internationale et pluridisciplinaire de religion grecque antique

$20 \mid 2007$

Varia

\section{Space and the notion of final frontier}

Searching for ritual boundaries in the Classical Athenian home

Janett E. Morgan

\section{(2) OpenEdition \\ 1 Journals}

\section{Electronic version}

URL: https://journals.openedition.org/kernos/175

DOI: $10.4000 /$ kernos. 175

ISSN: 2034-7871

\section{Publisher}

Centre international d'étude de la religion grecque antique

\section{Printed version}

Date of publication: 1 January 2007

Number of pages: 113-129

ISSN: 0776-3824

\section{Electronic reference}

Janett E. Morgan, "Space and the notion of final frontier", Kernos [Online], 20 | 2007, Online since 15

March 2011, connection on 08 September 2022. URL: http://journals.openedition.org/kernos/175; DOI: https://doi.org/10.4000/kernos. 175 


\title{
Space and the notion of final frontier: Searching for ritual boundaries in the Classical Athenian home
}

\begin{abstract}
The Classical Athenians were careful to separate the spaces of men from the spaces of gods. Yet when we look at the Athenian house, religious areas cannot be distinguished. This paper offers an investigation of how religious boundaries may be created by action and perception rather than bricks and mortar. Scholars of ancient Greek religion should not expect to see the permanence of public cult mirrored in domestic settings. One single, domestic space could host many activities; its meaning could be changed by ritual behaviour. The temporary nature of domestic space allowed the residents of the Athenian house the freedom to use their domestic spaces according to their needs, thus integrating the lives of gods and men in one location.

Résumé : Les Athéniens de la période classique prenaient bien soin de séparer les espaces des humains de ceux des dieux. Or, lorsqu'on regarde la maison athénienne, les zones religieuses ne peuvent être distinguées. Cet article explore la manière dont les limites religieuses peuvent être crées par un geste et une perception davantage que par des briques et du ciment. Les historiens de la religion grecque ancienne ne devraient pas s'attendre à voir la permanence du culte public se refléter dans les implantations domestiques. Un seul espace domestique pouvait accueillir de nombreuses activités; sa signification pouvait être transformée par un comportement religieux. La nature provisoire de l'espace domestique autorisait les habitants de la maison athénienne à user librement des espaces domestiques selon leurs besoins, mêlant dès lors la vie des dieux et celle des hommes en un seul lieu.
\end{abstract}

\section{Introduction}

The material remains of temples and shrines at classical Athens illustrate the importance of establishing a physical separation, a boundary between the spaces of gods and the spaces of men. ${ }^{1}$ Methods of division include walls, the

\footnotetext{
* My thanks go to the Arts and Humanities Research Council whose research scholarship enabled me to complete my PhD and to Nick Fisher, Ruth Westgate, Corinne Ondine Pache, Judy Barringer and the anonymous referees for their comments on the original text.

${ }^{1}$ I. MORRIS, Burial and society: the rise of the Greek city-state, Cambridge, CUP, 1987, p. 189-192, suggests that from 750 B.C. onwards the living spaces of men became more sharply separated from the spaces of gods. This is contested by C. SOURVINOU-INwOOD, "Early sanctuaries, the eighth century and ritual space: fragments of a discourse," in N. MARINATOS, R. HÄGG (eds.), Greek sanctuaries: new approaches, London/New York, Routledge, 1993, p. 1-17, who notes that public sacred spaces had always required a degree of differentiation. This is simply less easy to detect in the archaeological record for earlier periods.
} 
use of geographical features such as the Acropolis, or the placement of buildings and horos stones around an area, as can be seen in the Athenian Agora. ${ }^{2}$ Yet despite textual and material evidence indicating that ritual acts took place within the domestic context, boundaries between divine and mortal cannot be identified. The architecture of the classical Athenian house reveals no special ritual areas. Its spaces are multi-functional and a single location, such as the court, could host a wide range of events from industrial activities to family meals, as well as sacrifices to the gods. ${ }^{3}$ This flexibility has led to the prevailing view that, "Whereas public sacred areas were clearly differentiated from secular or profane space, the whole house was in effect the sacred precinct...."

It is certainly true that the house was treated as a single entity in respect to rites performed to purify or protect it. Yet it is difficult to believe that the Athenians, who were so careful to distinguish ritual spaces in the public sphere, had no rationale to govern the use of space within the house and take into account the very different nature of the acts performed there. ${ }^{5}$ In this paper, I will re-examine our approach to the investigation of domestic cult and will offer evidence that temporary ritual boundaries played a vital role in spatial negotiations within the classical Athenian home.

\section{Viewing ritual spaces}

Our failure to see ritual space in houses is a result of the way in which we view the domestic context. ${ }^{6}$ Excavators describe the rooms of classical houses

\footnotetext{
${ }^{2}$ Boundaries can also be investigated via evidence from inscriptions. The Acropolis was enclosed by a circuit wall, called the Pelargikon, which was used to, "delimit the sanctuaries," C.W. FORnARA (ed. and translator), Archaic times to the end of the Peloponnesian War, Cambridge, CUP, $1983^{2}$ [1977], (Translated Documents of Greece and Rome 1), p. 140, no.140. For a discussion of the Pelargikon, see J. Travlos, Pictorial Dictionary of Ancient Athens, London, Thames and Hudson, 1971, p. 52.

${ }^{3}$ The courtyard in House D from the Street of the Marble Workers, Athens, contained evidence of a large fire and metalworking: see R.S. YouNG, "An industrial district of ancient Athens," Hesperia (1951), p. 135-250. In a speech by Demosthenes, a family meal takes place in the courtyard, while in Plato, Respublica, the court is the location for a sacrificial event (Dem., 47, 53-56; Pl., Resp. I, 328c, 1-3).

${ }^{4}$ M.H. JAmeson, "Domestic space in the Greek city-state," in S. KENT, (ed.), Domestic architecture and the use of space: an interdisciplinary cross-cultural study, Cambridge, CUP, 1990, p. 92-113.

5 The whole house was purified on a regular basis according to a fragment written by Philochorus, 328 F 170 (ed. JACOBY). This is also the case when the Superstitious Man fears bewitchment by Hecate (Theophrastus, Characteres XVI, 7). Items such as herms, altars or plants were placed at the main door of the house to protect the space and family within, e.g., squill as in Aristophanes, fr. 255 (ed. KocK); R. KAssel, C. Austin, Poetae Comici Graeci, Vol. III.2, Berlin, de Gruyter, n. 266.

${ }^{6}$ Robert Parker, in his study of the contrast between textual and material evidence for the cult of Hestia, suggests that we give the textual evidence an, "over-literal conception". R. PARKER, Polytheism and society at Athens, Oxford, OUP, 2005, p. 15.
} 
as "living apartments", "kitchens", "bathrooms" and also "bedrooms". 7 These names imply that rooms have a single function, which can be determined from their architecture or artefacts. ${ }^{8}$ This contradicts evidence from classical texts, which hint at a more flexible approach to the use and definition of domestic space. ${ }^{9}$ The terminology that we use to describe the rooms of classical houses is based on our own, contemporary understanding of domestic space. ${ }^{10}$ Cahill has recently highlighted the arbitrary nature of the names that we use and points out that the English language often has no descriptive equivalents for these ancient rooms. ${ }^{11}$ Viewing the classical house through a modern, western oriented lens highlights any similarity with our own houses and obscures any domestic behaviour that differs from our own. ${ }^{12}$ This is of vital importance when studying the creation of domestic ritual spaces, as they can become

7 At Athens, Young, l.c. (n. 3), p. 203, records that House C has a "kitchen-bathroom" complex in its eastern portion. J.E. JONES, L.H. SACKETT, A.J. Graham, "The Dema House in Attica," ABSA 57 (1962), p. 75-114, indicate that the Dema House in the Attic countryside had living rooms, a kitchen and possibly bedrooms. At Olynthus, the functions of various rooms are described in general terms in D.M. RoBInSON, A.J.W. GRAHAM, Excavations at Olynthus, Part VIII: the Hellenic House, Baltimore, The Johns Hopkins University Press, 1938, p. 167-213. This contemporary terminology is applied specifically to the spaces in the House of Many Colours in D.M. RoBInson, Excavations at Olynthus, Part XII: Domestic and Public Architecture, Baltimore, The Johns Hopkins University Press, 1946, p. 183-206.

8 This approach has been criticized by J. BERRY, "Household artefacts: towards a re-interpretation of Roman domestic space," in R. Laurence, A. Wallace-Hadrill (eds.), Domestic space in the Roman world: Pompeii and beyond, Portsmouth, R.I, 1997 (JRA Supplement Series, 22), p. 183-196. N. CAHILL, Household and city organisation at Olynthus, New Haven/London, Yale University Press, 2002, p. 61-75, has similarly pointed out that such an analysis cannot be perfect, as it is based on limited excavation material that does not take into account changes in the use of either spaces or artefacts. The process of abandonment and choice of artefacts left behind can also skew attempts to reconstruct household activities, see V.M. LA MOTTA, M.B. SCHIFFER, "Formation processes of house floor assemblages," in P.M. ALLISON (ed.), The archaeology of bousehold activities, London, Routledge, 1999, p. 19-29.

${ }_{9}$ In the Lysias speech On the murder of Eratosthenes, the husband and wife move their living areas around with ease in order to accommodate the needs of a new baby.

${ }^{10}$ For a discussion of the role of modern perceptions in interpreting the past, see C. SourviNOU-INWOOD, Reading Greek culture: texts and images, rituals and myths, Oxford, Clarendon Press, 1991, p. 3-23. Similarly, L.C. NEVETT, House and society in the ancient Greek world, Cambridge, CUP, 1999, p. 30, writes that accumulated knowledge of the classical past from periods before our own awareness of ethnocentric assumptions developed may still unconsciously affect our interpretation of domestic space.

11 CAHILl, o.c. (n. 8), p. 123.

12 Models based on societies with a flexible approach to the use of space might provide more suitable ethnographic analogies. D. CANTER, K.H. LEE , "A non-reactive study of room usage in modern Japanese apartments," in D. CANTER, T. LEE, (eds.), Psychology and the built environment, New York, John Wiley and Sons, 1974, p. 49, note, "The West operates on the idea that each function has its own space... The Japanese house, however, names its rooms by their location... The use to which a space is put varies according to the time of day... Since these interiors conform to a number of needs, they actually serve no function at all... In other words, the Japanese house is functionally flexible." 
excluded by our lack of a means to describe them or our inability to comprehend the principles that govern their use.

Our view of the ancient domestic context is also influenced strongly by precedents from the public sphere. When we do not find the same clear, physical evidence of separate ritual spaces, we assume that it was not necessary to differentiate divine and mortal space within the house..$^{13}$ Yet this presumption ignores the obvious point that the ritual needs of a household and a city are not identical. The visible boundaries of public cult are monumental. They emphasize the value of these spaces to the city and mark them out as areas to be respected by all. Within the house, simpler methods could be used to create a ritual separation, involving the use of perishable materials such as textiles or plants. In Menander's play Phasma, ribbons cover a domestic shrine, creating a visual and symbolic separation of divine from mortal space within an internal room. ${ }^{14}$ This private ritual boundary has the same validity and serves the same purpose as a public one, yet we would find it difficult to locate through archaeological investigation alone.

Archaeology can tell us how space is used, but it cannot tell us why. The issue of meaning is of vital importance in any study of ritual space since we can see that although they had identifiable physical characteristics, public ritual boundaries were also and more importantly constructed in the mind. Ritual space requires an act of faith on the part of the participant - a belief that the area they are about to enter differs from the space around it. This duality is reflected in the comment by Hippocrates that, "We ourselves fix boundaries to the sanctuaries and precincts of the gods, so that nobody may cross them unless he be pure." 15 In the private context, a family might create boundaries by ritual behaviour rather than physical demarcation. The action of circling and purifying an altar indicates to ritual participants that this area is marked and special. ${ }^{16}$ This type of spatial negotiation is as valid as any wall around a

13 JAMESON, l.c. (n. 4), p. 105, indicates that the external walls were sufficient to provide a sacred boundary for the whole house. Yet, given the poor preservation of most classical houses, these are simply the only boundaries that can be observed.

${ }^{14}$ Menander, Phasma, 52-56. The ribbons also offer a convenient means of covering the area, enabling the mother to meet her daughter in secret. The use of tapestries to create a suitable space for dining in a symposium can be seen in passage by Aristophanes (Vespas, 1215), whilst a fragment by Hyperides (Pollux, IV, 122) mentions the division of a stoa by the use of a curtain.

15 Hippocrates, Morb. sacr. IV, 55.

16 The circling and purification of a domestic altar can be seen in the Euripides play The Madness of Hercules (Eur., HF, 922-930). R. PARKER, Miasma: pollution and purification in early Greek religion, Oxford, Clarendon Press, 1983, p. 23, notes that purification can mark off sacred places from profane. Yet it can also be seen as a division between ritual and non-ritual space. J. Bremmer, "Religion', 'Ritual' and the opposition 'Sacred vs. Profane'," in F. Graf (ed.), Ansichten griechischer Rituale: Geburtstags-Symposium für Walter Burkert, Castelen bei Basel, 15 bis 18. Marz 1996, Stuttgart, B.G. Teubner, 1998, p. 10-32, has questioned our use of the terms sacred-profane 
sanctuary, yet we cannot view it in the material record. In order to understand domestic ritual space we must first consider how it is given meaning, this can only be achieved by a careful examination of ritual behaviour in classical texts.

\section{The language of Athenian domestic space}

Let us first consider whether domestic terminology reveals any information about the meaning and construction of domestic spaces. Athenian texts of the classical period most frequently refer to a room either as a domos or melathron, a thalamos or occasionally an oikos and there is no obvious rationale that governs when a particular word is selected. ${ }^{17}$ None of these terms reflect a definition of space by function; neither do they offer direct information about the performance of cult acts in the house. Yet the words used to describe the rooms of the classical house do offer insights into the manner in which meaning was ascribed to domestic spaces. The terms domos, melathron, thalamos and oikos are applied to built environments with a wide range of different uses, as can be seen in the following table. The absence of specific terms raises the possibility that the roles played by spaces could be changed. Rooms could be viewed as a blank canvas, capable of being given different meanings according to the needs of the members of a household.

Table illustrating the meanings of domestic terms

\begin{tabular}{|c|c|c|}
\hline Word & Meaning & Contexts of use \\
\hline 1. $\delta o ́ \mu o s-d o m o s$ & $\begin{array}{l}\text { Built place } \\
\text { (derived from verb to build) }\end{array}$ & $\begin{array}{l}\text { Temple, House, Household, } \\
\text { Room. }\end{array}$ \\
\hline 2. $\mu \varepsilon ́ \lambda \alpha \theta \varrho o \nu-m e l a t h r o n$ & Roofed place & House, Room, Byre \\
\hline 3. oinos - oikos & Space pertaining to household & $\begin{array}{l}\text { Temple, House, Household, } \\
\text { Room }\end{array}$ \\
\hline 4. $\theta \dot{\alpha} \lambda \alpha \mu o s-$ thalamos & Private space & $\begin{array}{l}\text { Room, Women's Room, } \\
\text { Bedroom, Bride Chamber, } \\
\text { Store, Ship's Hold, Sheep Pen }\end{array}$ \\
\hline 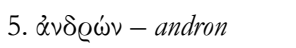 & Men's space & Male space in the house \\
\hline 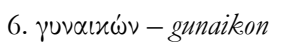 & Women's space & Female space in the house \\
\hline 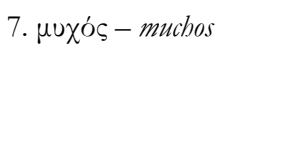 & Space & $\begin{array}{l}\text { Innermost space, corner, } \\
\text { recess, edge, room, temple } \\
\text { space, store, valley, harbour, } \\
\text { coastal inlet, depths of the sea }\end{array}$ \\
\hline
\end{tabular}

and suggests that as modern constructs they offer little insight into how the classical Athenians might have viewed such divisions.

17 Thus, in a single play, the paternal home of Hercules is referred to as a domos (Eur., HF, 138-139), an oikes (Eur., HF, 327-331) and a melathron (Eur., HF, 336-338). 
The generic nature of domos, melathron, thalamos and oikos contrasts with the fifth and sixth terms, andron and gunaikon. These words appear to indicate a more specific form of spatial distinction, although it is based on gender not ritual. Male and female spaces are difficult to identify in the material remains of the classical Athenian house and the words themselves rarely appear in texts. ${ }^{18}$ In their discussion on clothing terminology, Kurtz and Boardman have noted that the over-precise identification of "technical" words can result in the exclusion of wider associations and restrict our ability to understand. ${ }^{19}$ In seeking to tie the andron and gunaikon to particular areas in ancient houses we limit our ability to learn how these spaces were constructed and given meaning.

In using definitive labels to describe ancient rooms we ignore the fundamental issue, raised earlier, that it is not walls or words that give a space meaning. The names andron and gunaikon, male and female space, offer an indication of the individuals who are using a particular room. These words may have offered a description of space that was specific to an occasion, a gathering that was limited according to gender. Removal of the circumstances justifying gender segregation might also have removed the need to identify the space with these names. The role of human action in spatial definition is recognized by the orator Aeschines who comments:

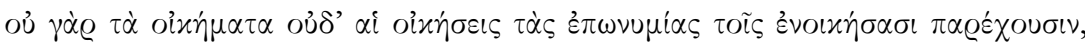

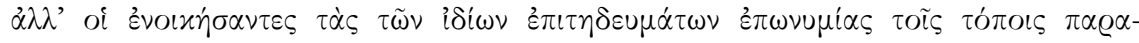

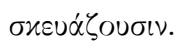

For it is neither the dwelling places nor the houses, which give their names to those living in them, but it is the inhabitants who give to the places the names of their own practices. ${ }^{20}$

\footnotetext{
18 The term andron was used by RoBinson, GraHAM, o.c. (n. 7), p. 171-172. They use it to refer to rooms with borders and mosaics at Olynthus. Similar spaces are not found in Athenian houses until the fourth century B.C., despite the fact that the term andron is used in Athenian texts of he fifth century B.C. Here it most frequently describes spatial divisions in palaces, including the palaces of eastern kings at Susa and Lydia (Herodotus, I, 34, 15-16; III, 77, 13-16). It seems possible that the ownership of a private andron in relation was linked to the role of eastern symbols as a means of self-definition: see M.C. Millar, Athens and Persia in the fifth century BC: a study in cultural receptivity, Cambridge, CUP, 1997. With regard to the gunaikon, textual evidence suggests that this was more social ideal than permanent architectural feature: see L.C. NEVETT, "Separation or seclusion? Towards an archaeological approach to investigate women in the Greek household in the third to fifth centuries BC," in M. PARKER-ПEARSON, C. Richards (eds.), Architecture and order: approaches to social space, London/New York, Routledge, 1994, p. 98112.

19 D.C. Kurtz, J. Boardman, "Booners," in J. Frel, S. Knudsen Morgan (eds.), Greek Vases in the J. Paul Getty Museum, Malibu, The J. Paul Getty Museum, 1985 (Occasional Papers on Antiquities, 2), p. 35-70. A similar point has also been made by NeveTt, o.c. (n. 10), p. 18, when discussing the appearance of gendered terms in texts relating to the Athenian house.

${ }^{20}$ Aeschines, In Timarchus, 123-124.
} 
This is of great importance for the investigation of ritual space in the classical Athenian home, for it confirms that meaning can be ascribed on a temporary basis through the presence of certain individuals or through their actions..$^{21}$

\section{Meaning and the construction of domestic space}

We can find confirmation of the role of individuals and acts in giving meaning to domestic spaces by looking more closely at the term muchos. Ancient writers use this word to describe the interior spaces of residences, whether the palaces of Homer or the houses of Menander, yet no clear description is ever given of its structure or decoration, as is the case with spaces denoted by the generic terms discussed earlier. ${ }^{22}$ Its decoration is of less importance than its meaning as a private space. This meaning can be seen in the association of certain items, individuals and acts with the muchos. It is a place where valuable things can be stored; the muchos in Sophocles' Women of Trachis, is the place where Deianeira is advised to store the precious love potion. ${ }^{23}$ It has strong associations with women; Euripides uses the term muchos to describe the area where female captives are placed in Trojan Women as well as Hecuba. ${ }^{24}$ It is a special, private place where a god may be contacted. ${ }^{25}$ Aeschylus places a muchos in Apollo's temple at the start of the Eumenides, while Medea reveals that Hecate dwells in the muchos of her hearth. ${ }^{26}$ Finally, the muchos is the place where the private activities of sleep and sex may occur. ${ }^{27}$

${ }^{21}$ The meaning of a space or item can derive from its symbolic importance, rather than its physical existence. PARKER, o.c. (n.6), p.14, discusses how the centrality of the household hearth is synonymous with the continuity of the oikos, rather than its fireplace. This supports the notion that meaning is perceived by the user rather than vested in an object.

22 Odysseus describes the construction of his bed and thalamos (Homer, Odyssey XXIII, 181204) while Xenophon describes the contents and physical characteristics of rooms in the house of Ischomachus (Xenophon, Oeconomicus IX, 2-5).

${ }^{23}$ Sophocles, Tracbiniae, 685-686. The importance of the muchos as a storage place is reflected in its appearance as a place where cities stored their treasures (Xenophanes, II, $22=$ Athenaeus, $\mathrm{X}, 413)$.

24 Euripedes, Hecuba, 1040; Troades, 298-299. In both of these cases the women are also captives and valuable as well as vulnerable.

25 As humans cannot look directly upon gods, the meeting between deity and priest or priestess must take place in a dark and safe area. The association of gods and muchoi is reinforced in the cosmology of Pherekydes, where the deities emerge from the muchoi. See H.S. SCHIBLI, Pherekydes of Syros, Oxford/New York, Clarendon Press, 1990.

${ }^{26}$ Euripides, Medea, 397.

27 The muchos is an area where nymphs retire for sex (Hymnus Homericus ad Venerem V, 262263). It is also directly connected with illicit lovemaking in a fragment by Callias (R. KASSEL, C. Austin, Poetae Comici Graeci Vol. IV, Berlin, de Gruyter, 1983-, n. 1), which suggests that the adulterer should be thrown out of the muchos. It is where Achilles sleeps in the Iliad (Hom., Il. IX, 663; XXIV, 675) and where the master of the household placed his bed (Hymnus Homericus ad Cererem II, 141-144). 
These individuals and activities require a space that is hidden or protected. The muchos is thus a safe place, suitable for vulnerable persons and private acts. Its protective ability stems from the fact that it is an area that cannot be clearly seen and, as such, it is an area of darkness and privacy. Yet the fact that the muchos can be identified or distinguished from other spaces suggests that there may also be a physical element to its construction. The domestic muchos is a space not defined in a permanent sense by its walls, but by the belief that the dark places within the house are safe places. ${ }^{28}$ This idea is reinforced in Sophocles' Women of Trachis when Deianeira describes the instructions given to her for the storing of the 'love potion:'

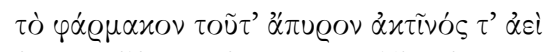

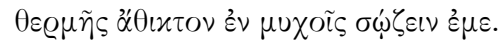

I was to save the drug in the muchos, away from the fire and untouched by the warm rays of the sun. ${ }^{29}$

The muchos then is a space whose boundaries are not created by brick but by the perceived contrast between light, which makes space visible and vulnerable, and darkness, which renders it unseen and safe.

The defining characteristic of darkness also helps us to understand the most unique feature of the muchos; it can exist as a portion of a room as well as a single, distinct space. Thus baby Hercules is attacked by snakes while sleeping in the muchos of the thalamos:

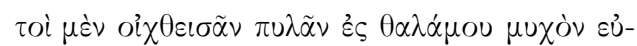

Qùv $\varepsilon \beta \alpha \nu$

And when the gates had been opened, they went into the broad muchos of the thalamos. ${ }^{30}$

Similarly, Solon's description of the entry of evil into the house is intended to strike fear into its audience by virtue of the fact that it has reached even within the muchos of the most private room, the thalamos:

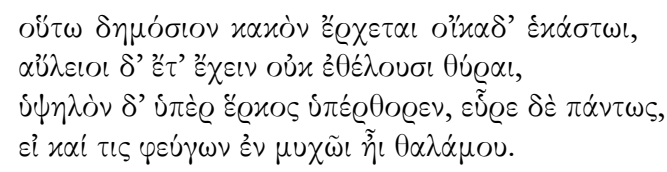

\footnotetext{
28 These ideas and the association of the muchos with women are perhaps reflected in Aristophanes use of the word muchos to describe female genitalia (Aristophanes, Ecclesiazusae, 7-15). They also mirror the connection between the muchos and sex.

${ }^{29}$ Soph., Trach., 685-686.

${ }^{30}$ Pindar, Nemean I, 41-42.
} 
Thus common evil comes to the house of each, and yet the doors of the court do not have the power to hold it, but it leaps high over the boundary fence and it finds all, even if one flees within the muchos of the thalamos. ${ }^{31}$

When Polymestor threatens to break into the muchos where the female captives have been placed in Hecuba, the building he is referring to is a campaign tent. ${ }^{32}$ Despite being a temporary residence, its innermost parts can be distinguished from other spaces and invaded. These three examples raise another issue of great importance in understanding the construction of ritual spaces in the Athenian house for they confirm that a single space can hold more than one meaning. Ritual space could therefore be localized; focused on the area around one individual or created on a temporary basis by the performance of certain acts or the use of perishable markings.

\section{Creating rituel spaces}

Let us turn now to descriptions of ritual acts and consider how the separation or creation of ritual spaces is achieved. Two fragments from plays by Menander offer valuable information on the role of the body and action in dividing ritual from domestic space. In the first extract, the character Pheidias seeks a cure for love-sickness, having fallen in love with what he believes to be a beautiful, female apparition, viewed at a domestic shrine:

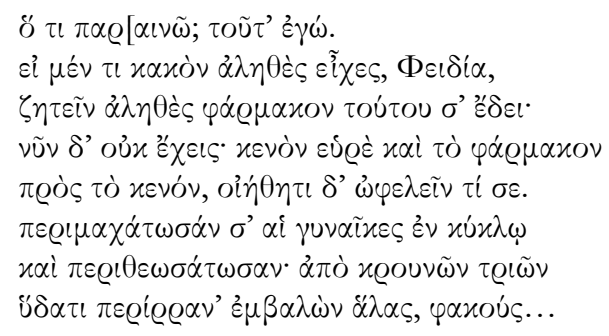

What do I advise? I say this. If this had been a real problem, Pheidias, you would have had to seek a real remedy for this. But yet you have not, so find a fake medicine for your fake illness and believe that it helps you. Let the women in a circle wipe all around you and burn incense around you. Sprinkle around water from three springs, throwing on salt, lentils. ${ }^{33}$

Although this is a comic passage, the ritual acts performed by the participants suggest that it may be a parody of a purification rite. The obvious scepticism of the speaker does not diminish the expressed belief that perform-

\footnotetext{
${ }^{31}$ Solon, IV, 27-9 = Demosthenes, De Falsa Legatione XIX, 255, 37-40 (Loeb Classical Library).

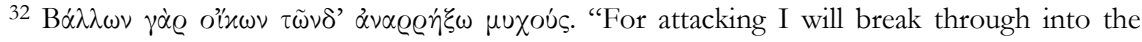
inner parts of this residence" (Eur., Hec., 1040).

33 Men., Phasm., 24-31.
} 
ing such rites could benefit a recipient. ${ }^{34}$ Indeed the speaker acknowledges the role of the patient's mind in such matters - "believe that it helps you." Pheidias is given a central position in the rite in both a physical and metaphysical sense. $\mathrm{He}$ sits at the centre and his body defines the space on this occasion, just as the vulnerable family members define the space of the muchos. Pheidias is the focal point of the ritual action. The participating women encircle him and their bodies mark the space around Pheidias, creating a physical and also symbolic boundary. We can see a similar creation of ritual space in the actions of the female chorus. ${ }^{35}$ As Lonsdale notes, "one of the primary functions of dance is to establish a sense of place, to control a boundary by putting the feet in contact with the earth and circumscribing an area with a chain of human bodies. ${ }^{\prime 36}$ The placement of the women around Pheidias defines, describes and separates a ritual space within the room.

The acts performed by the women not only have ritual significance but also affect the senses. The women wash Pheidias, marking him and the space around him as pure, just as a man might wash before entering a sanctuary. They also burn a scented substance. The smell of the scent highlights the difference between their space and the spaces around them. It also marks the individuals who breathe it as a discrete group, in the same way that consumption of the sacrificed animal marks the sacrificial community. To further enhance the notion of purity and separation, water is sprinkled around, with salt and lentils. The purificatory role of salt is well attested, lentils less so. ${ }^{37} \mathrm{It}$ is possible that as the lentils fall to the ground they mark the space of the purification, thus further emphasising the difference between this space and the space around it. Via sight, sound and smell, the meaning given to the space is altered to permit a

\footnotetext{
34 The acts performed in this rite seek to manipulate circumstances and might therefore be considered to be magical in nature. Nonetheless, the rite involves certain proscribed acts and can also be considered as evidence of ritual behaviour. For discussions on the magic vs. religion debate, see J. BrAAVIG, "Magic: Reconsidering the grand dichotomy," in D.R. JORDAN, H. Montgomery, E. Thomassen (eds.), The world of ancient magic: Papers from the First International Samson Eitrem Seminar at the Norwegian Institute at Athens, 4-8 May 1997, Bergen, The Norwegian Institute at Athens, 1999, p. 21-54; M.W. DiCKIE, Magic and magicians in the Greco-Roman world, London/New York, Routledge, 2001, p. 18-46; and F. GRAF, "Excluding the charming: The development of the Greek concept of magic," in M. MEYER, P. MireCKI (eds.), Ancient magic and ritual power, Leiden/New York, E.J. Brill, 1995, p. 29-42.

${ }^{35}$ For a description of the importance of circularity to the female chorus, see C. CALAmE, Choruses of young women in ancient Greece: their morphology, religious role and social function (Translated by D. Collins and J. Orion), London, Rowman and Littlefield Publishers Inc, $1997^{2}$ [1977], p. 34.

36 S.H. LonsDale, Dance and ritual play in Greek religion, Baltimore/London, The Johns Hopkins University Press, 1993, p. 120.

${ }^{37}$ Seawater, with its high salt content, is referred to often as a means of purifying. It is used to cleanse the corpse (Eur., Hec., 609-613) and also to wash sacred statues. See W. BuRKERT, Greek religion: Archaic and Classical (Translated by J. Raffan), Oxford, Blackwell, $1985^{2}$ [1977], p. 78-79. It is possible that the lentils have a comic role, however lentils and pulses were used in ritual meals, such as the Anthesteria and their precise meaning here is thus difficult to access.
} 
belief that the central individual and participants in the rite are in a separated space.

A similar ritual takes place in the second Menander fragment from the play Misogynist:

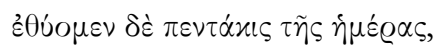

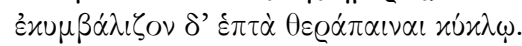

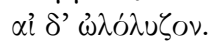

And we were burning incense five times a day, and seven serving girls were playing the cymbals in a circle whilst they cried the ritual chant. ${ }^{38}$

Here, again, the burning of a scented substance creates an atmosphere and, as in the first fragment, women mark the space. Again, they form a circle, defining and enclosing the sacred area and also, possibly, the location of the other participants. ${ }^{39}$ In this rite, the separation is further enhanced by sound. The women cry out and beat cymbals. The effect of the noise is to focus attention on what is taking place. That their acts have sacred connotations is implicit in the use of the verb $\delta \lambda o \lambda \dot{\gamma} \zeta \omega$. The women raise the sacred cry aimed at the gods in moments of religious joy or grief. ${ }^{40} \mathrm{It}$ is possible that the clash of the cymbals or the pattern of the shouting symbolically joined the women so that they operated in unison. This ritual noise further enhanced the perception of the space as enclosed and also protected. ${ }^{41}$

The precise location of the acts performed is irrelevant. The rooms do not give meaning to the rites, but rather the ritual action and belief of the participants create a separate and defined space within the room. On completion of the purification, the area reverts to its previous use. Ritual space is temporary and acts and individuals, not architecture, give it its meaning.

\section{Rites of transition. A spatial perspective}

The temporary construction of ritual space has important implications for the study of rites within the classical Athenian home especially those concerned with life-cycle transitions in the domestic context. We know that these occasions required the household to amend its behaviour in order to control

\footnotetext{
38 Menander, Misogynist fr. 326 (ed. Kock): R. Kassel, C. Austin, Poetae Comici Graeci Vol. VI.2, Berlin, de Gruyter, 1983-, n. 237.

39 The image of the circled object also appears in connection with other sacred rites, e.g., Plato describes how seats were placed in a circle at a sacrifice (Pl., Resp. I, 328c).

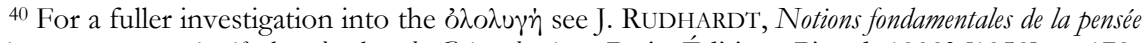
religieuse et actes constitutifs du culte dans la Grèce classique, Paris, Éditions Picard, $1992^{2}$ [1958], p. 178180.

${ }^{41}$ The use of drums, scent and other forms of purification are referred to by Theophrastus (Char. XIV), Plutarch (De Superstio, 11 [171b]) and Hippocrates (Morb. sacr. IV, 55).
} 
the resulting pollution and protect household and community. ${ }^{42}$ It is also possible to see in these rites evidence for the creation and regulation of ritual space as a means to successfully negotiate the changes taking place in the composition of the family. In this section I will focus on the spatial semantics of death rites. ${ }^{43}$ We know of the behaviour of the household on the death of a family member from law court speeches, tragedy and comedy. ${ }^{44}$ Although I acknowledge that the latter two sources do not offer direct representations of domestic events, there is enough consistency in the images they present to suggest that they reflect contemporary practices. Plays offer a "symbolic representation of social behaviour" and are of enormous value to investigations of the domestic sphere. ${ }^{45}$

Following a death, the first act of the household was to protect the community by creating a boundary between house and city. The family withdrew socially, confining themselves within the house and placed signs at the door to indicate this separation and to act as a warning to others, enabling them to avoid contamination. ${ }^{46}$ We can see this separation and the use of symbolic markers in Euripides' play Alcestis. ${ }^{47}$ As the Chorus of citizens of Pherae draw near to the house of Admetus they look for signs that the death of Alcestis has taken place. They listen for the sound of mourning and look for a water vessel and a lock of cut hair at the gates of the palace. ${ }^{48}$ The use of water, or, more accurately, washing bowls, to distinguish ritual space from living space was also a feature of public sites that offered tangible evidence of a symbolic boundary. The position of the water and lock of cut hair at the front door, the mediating point between home and community, indicated a division in space, a boundary,

\footnotetext{
${ }^{42}$ For a detailed discussion of the concept and effects of pollution, see PARKER, o.c. (n. 16).

${ }^{43}$ For studies of the textual and iconographic evidence for death, see K. STEARS, "Death becomes her: gender and Athenian death ritual," in S. Blundell, M. Williamson (eds.), The sacred and the feminine in ancient Greece, London, Routledge, 1998, p.113-127; R. GARLAND, "The well-ordered corpse: an investigation into the motives behind Greek funerary legislation," BICS 36 (1989), p. 1-15; R. GARLAND, The Greek way of death, New York, Duckworth, $2001^{2}$ [1985].

${ }^{44}$ All of the texts in the following discussion were written in the classical period and are from Athens.

45 C. SEGAL, "Euripides' Alcestis: how to die a normal death in Greek tragedy." In S. WEBSter Goodwin, E. Bronfen (eds.), Death and representation, Baltimore, The Johns Hopkins University Press, 1993, p., 213-214.

46 In the play Aspis, Menander presents an extreme picture of social separation. The women are secluded and only able to communicate with the outside through drainage channels (Men., Aspis, 466).

${ }^{47}$ Euripides, Alcestis, 98-104.

48 Aristophanes mentions the use of a water vessel at the door of a corpse's house (Ar., Eccl., 1032-1033). These may be the signs that the Superstitious Man observes in seeking to avoid houses of death (Theophr., Char. XIV, 9).
} 
between the city and the house where ritual was playing a dominant, albeit temporary, role. ${ }^{49}$

We have no evidence to suggest that the body was isolated from the family members within the house. Iconographic representations of the prothesis, the laying out of the corpse, indicate that the location of corpse and bier were flexible; some vases show outdoor locations, others show evidence of domestic interiors. ${ }^{50}$ Demosthenes informs us that, according to the laws of Solon, the corpse was placed endon - within:

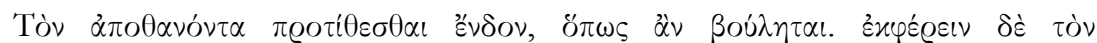

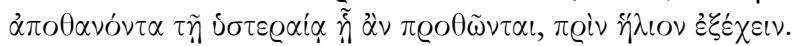

The deceased shall be laid out within, however one wishes. And they shall carry out the corpse on the next day after the laying out, before the sun rises. ${ }^{51}$

This same law also bans women under sixty from entering the room where

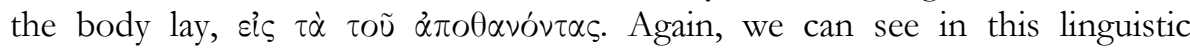
flexibility confirmation of the idea that location is less important than ritual action. Spatial meaning is not conferred by descriptive terminology but by the actions of the family in relation to the corpse. These actions bear certain similarities to the purification rites of Menander's Phasma and Misogynist, discussed above.

At death, the ritual action began by focussing directly on the deceased. The deceased was no longer a part of the living family group but became an, "attention-focusing device". 52 The body became the centre around which the space of the house and the acts of the household were articulated. The deceased was washed and purified by the family. ${ }^{53}$ This purity marked the central individual and separated him from the participants. Yet washing alone

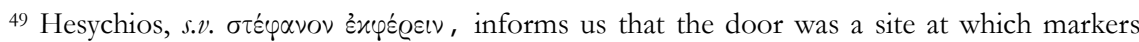
indicating changes in the structure of the family were made public, olive branch for the birth of a boy, wool for a girl. See R. GARLAND, The Greek way of life from conception to old age, London, Duckworth, 1990, p. 75.

50 See J. BoARdman, "Painted funerary plaques and some remarks on prothesis," ABS A 50 (1955), 51-66; D.C. KurTZ, "Vases for the dead: An Attic selection 750-400 BC," in H.A.G. BRIJDER (ed.), Ancient Greek and related pottery: proceedings of the International Vase Symposium in Amsterdam, 12-15 April 1984, Amsterdam, Allard Pierson Series, 1984, p. 314-328. More recently Brigger and Giovannini have suggested that the corpse was placed before the house in an especially constructed funeral tent: see E. BRIGGER, A. GIOVANNINI, "Prothésis. Étude sur les rites funéraires chez les Grecs et chez les Étrusques,” MEFRA 116 (2004), 179-248, especially 230234.

51 Dem. 43, 62.

52 This phrase is used by C. RENFrEw, The archaeology of cult: the sanctuary at Phylakopi, London, Thames and Hudson, 1985, p. 11-26, to describe an artefact that provides a symbolic focus for ritual occasions. Although he is discussing material evidence the textual evidence for the treatment of the corpse suggests that it can be considered in the same manner.

${ }^{53}$ An example of the washing of the corpse can be seen in Hecuba (Eur., Hec., 609-613). For the rites focused on the corpse, see GARLAND, o.c. (n. 43), p. 21-47.
} 
was not sufficient, the family emphasized its separation further by dressing the deceased in special clothes and placing a crown, symbol of purity, on his head. ${ }^{54}$ Aristophanes uses these acts as comic material in a passage from Assembly Women:

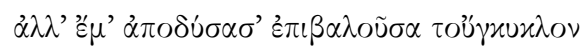

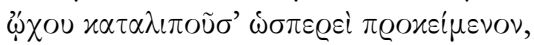

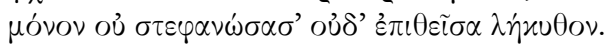

But stripping me of my clothes and throwing down your top you went off leaving me as if I were laid out only without crowning me nor putting the lekythos beside me. ${ }^{55}$

The purification and adornment of the corpse set it apart from the family in a visual as well as a metaphysical sense.

We have already seen in the two Menander passages that the actions of enclosing or surrounding and ritual movement could play a vital role in creating a separated ritual space within the domestic context. Images of the prothesis indicate that the mourners surrounded the body of the deceased. ${ }^{56}$ The mourners stood at both sides of the bier as well as at the top and bottom. ${ }^{57}$ They appear to be arranged in specific positions according to gender, with women at the head and sides and men at the feet of the corpse. ${ }^{58}$ The women's positions may indicate the different roles played by family members in the rites; women's closer connection to pollution, as well as purification made them a particularly effective means of marking a ritual boundary. ${ }^{9}$ The female circle moved their arms in gestures that played an apotropaic or protective role, as well as expressing their grief. ${ }^{60}$ Certain images of mourning indicate that the

\footnotetext{
54 The adornment of the corpse can be seen in Eur., Tro., 1210. For the wearing of crowns or garlands, see Eur., Tro., 1217; Aristophanes, Lysistrata, 599-604.

55 Ar., Eccl., 536-538.

56 See BOARDMAN, l.c. (n. 50); H.A. SHAPIRO, "The iconography of mourning in Athenian art," AJA 95 (1991), p. 629-656.

57 For figures either side of the bier, see Red-figured loutrophoros. Munich Staatliche Antikensammlungen, von Schoen Collection 66 in SHAPIRO, l.c. (n. 56), Fig. 18.

${ }^{58}$ H. VAN WEES, "A brief history of tears: gender differentiation in archaic Greece," in L. Foxhall, J. SALmON (eds.), When men were men: masculinity, power and identity in Classical Antiquity, London/New York, Routledge, 1998, p.10-53, has suggested that these stylised movements are part of an artistic convention for representing funerals, differentiating between male and female grief. However, it is interesting that similar movements continue to be shown on the rarer fifth century images of the prothesis, despite, as SHAPIRO, l.c. (n. 56), p.56, has noted, the change in focus to a more personal style of portrayal.

59 BRIGGER - GIOVANNINI, l.c. (n. 50), p.231-233, note that the mourners are positioned around the corpse according to their relationship with the deceased. The closest relations enclose the body. Thus the space of the corpse is marked out by the degree of contact given to mourners.

${ }^{60}$ M.H. Delavaud Roux, Les dances pacifiques en Grèce antique, Aix-en-Provence, Publications de l'Université de Provence, 1994, p. 135, describes the movements as part of a gestural code, similar to that of Thai dancers.
} 
mourners may have moved around the bier, circling the deceased. ${ }^{61}$ As we have already seen, movement plays an essential role in describing space and in creating boundaries:

The circular movement of a group around (peri) any significant object is the characteristic configuration of the choral band, who in linking bodies establish boundaries. It is vital that the circle be drawn around the corpse so as to contain its noxious effects and protect it from pollution from without. ${ }^{62}$

Just as the drums, chanting and movement enhanced the creation of a temporary ritual space in the fragment from Menander's Misogynist, discussed earlier, so the movement and sound of the lament unified the mourning group. Each individual played a role in the creation of a sound that moved around and through the participating family members and emphasized their unity and their separation from the community outside. ${ }^{63}$ Through movement, gesture and noise the family marked the space around the corpse and emphasized the separation between dead and living family members.

We can also see that artefacts and plants were placed around and under the corpse, marking the space where it lay and reinforcing the visual separation of the body. ${ }^{64}$ These items are mentioned in a passage from Aristophanes' Assembly Women:

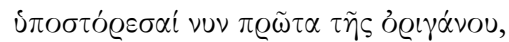

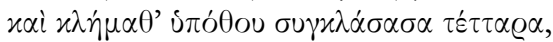

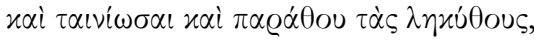

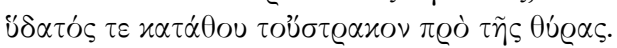

now first strew some oregano, break off four vine twigs and place them under and bind yourself with a ribbon and place the lekythoi beside and put down an earthen water vessel before your door. ${ }^{65}$

All of these artefacts may have had practical roles; the herbs may have helped to ward off flies, the ribbons may have bound the mouth and the lekythoi may have contained oil or perfumes as a gift for the deceased. However, it is also possible that their position near the corpse had a more symbolic dimen-

\footnotetext{
${ }^{61}$ STEARS, l.c. (n. 43). See also the movement of drapery on the central mourner who is facing away from the deceased on the red-figured loutrophoros. Munich Staatliche Antikensammlungen, von Schoen Collection 66. SHAPIRO, l.c. (n. 56), Fig. 18. The circling of the corpse is also described in Hom., Il. XXIII, 13-14.

${ }^{62}$ LONSDALE, o.c. (n. 36), p. 250.

${ }^{63}$ For a study of participation in mourning laments and the unity of the participating group see C.N. Seremetakis, The Last Word: Women, Death and Divination in Inner Mani, Chicago, The University of Chicago Press, 1991.

${ }^{64}$ We find this in texts: see Ar., fr. 205.1; fr. 210 (ed. KOCK): KASSEL - Austin, o.c. (n. 27), Vol. III, 2, n. 210, n. 216; Ar., Lys., 603. It can also be seen in iconography: see BRIGGER GiovanNini, l.c. (n. 50), p.231.

65 Ar., Eccl., 1030-1033.
} 
sion. The lekythos had a strong association with all aspects of death from its place at the side of the body in the house to its role as grave marker or gift to the deceased. ${ }^{66}$ Ribbons and wreaths decorated the grave as well as the area in which the corpse lay. ${ }^{67}$ The appearance of these items at home and at grave suggests continuities between the two spaces. Similarly we can see in the placement of mourners around the cart carrying the bier to the grave and the continued lamenting and ritual actions of the funerary procession that the ritual boundary was maintained as the corpse was carried through the city to its new home at the graveyard. ${ }^{68}$ This offered protection to the community while death travelled its streets. Once placed in its new home, the corpse would receive gifts from the family, reflecting the continued connection between family and deceased despite their new spatial arrangements.

Rites of transition required the creation of a separated space within the home, which allowed the family to integrate the changes that had taken place to the family unit. The family created this ritual space by their acts, which focused on the individual undergoing the transition. We have seen how, in the case of death, the space around the corpse was created to protect and isolate it. The ritual controls on the house and family came to an end as the circumstances that required their creation ended. The ritual space within the house dissolved with the exit of the corpse and, as the pollution receded, the house rejoined the community.

\section{Conclusion}

The demarcation of ritual spaces in the public sphere cannot be used as a model for investigations of ritual spaces in classical houses. Public cult places have a degree of monumentality that was not necessarily relevant within the home. Although public cult places illustrate the importance of creating a boundary, we should not expect the materials used in public and private contexts to be the same. If we search for permanent physical boundaries as markers of sacred spaces within the Athenian house, we will be disappointed.

66 A.H. Sommerstein, Ecclesiazusae: Comedies of Aristophanes 10, Warminster, Aris and Phillips Ltd, 1998, p.185, calls the lekythos the prime symbol of death. Reference is made at line 996 to the painter of lekythoi for funerals, at line 1032 the old women is advised to prepare a funeral bier with lekythoi and at line 1111 it is used as a grave marker.

${ }^{67}$ Ar., Eccl., 1032-1033. D.C. KuRTZ, Athenian white lekythoi: patterns and painters, Oxford, 1975, p. 50 , has suggested that the ribbons did not have an especially funerary significance as they also appear in wedding imagery. She suggests that they have more general cult significance setting off the object that they adorn from a common to a special use. BOARDMAN, l.c. (n. 50), p. 56, notes that when they hang from walls or even the kline they may mark a ritual space apart from other domestic areas.

${ }^{68}$ For images of the funeral procession with women continuing to raise their arms in ritual gesture, see E. Vermeule, Aspects of death in early Greek art and poetry, Berkeley CA, University of California Press, 1981, p. 20, Fig. 15 and 16. 
The ritual boundaries of the classical Athenian house were temporary rather than permanent, metaphysical more than physical. They required belief, bodies and actions not bricks. Through changing the meaning of a given space at a given time, temporary boundaries could be created and ritual and domestic space could co-exist within the classical Athenian home.

Janett E. MORGAN

Bristol University

Departement of Classics and Ancient History

11 Woodland Road

BRISTOL, BS8 1TB

E-mail:janett@morganfamily.fsnet.co.uk. 